Gambaran Histologi Organ Hepar Mencit Betina Bunting (Mus musculus L.) Setelah Pemberian Air Rebusan Mi Instan

\title{
The Effect of Water Instant Noodle on Histologycal Appearance of Pregnant Mice (Mus musculus L.)
}

\author{
Sister Sianturi, \\ Program Studi S-1 Farmasi STIKES Dirgahayu Samarinda, Jl. Pasundan No. 21, Kelurahan \\ Jawa, Kecamatan Samarinda Ulu, Kalimantan Timur \\ *Alamat E-mail Korespondensi : sianturisister16@gmail.com
}

Submit April $2021 \quad$ Revisi Mei $2021 \quad$ Diterima Mei $2021 \quad$ Terbit Juni 2021

\begin{abstract}
ABSTRAK
Penelitian ini dilakukan sebagai lanjutan dari penelitian sebelumnya yaitu uji pemberian air rebusan mie instan pada mencit betina bunting dan diperoleh hasil bahwa terdapat kelainan fetus tetapi pada analisis statistic kelainan tersebut tidak signifikan. Penelitian ini dilakukan untuk mengetahui gambaran histologi organ hepar mencit betina bunting setelah pemberian air rebusan mie instan. Tahapan penelitian ini adalah sebagai berikut: persiapan hewan uji mencit betina bunting yang sudah diberi perlakuan air rebusan mie instan dari 3 merek yang berbeda yaitu P1, P2, dan P3.Masing-masing perlakuan tersebut terdiri atas pemberian air rebusan dengan konsentrasi yang berbeda yaitu 30\%, $50 \%$, dan $70 \%$ selama 14 hari, kemudian mencit dikorbankan lalu diambil organ hepar, pembuatan preparat histology, lalu diamati struktur histologinya. Metode pembuatan preparat histologi mengikuti prosedur pewarnaan HE (Haematoxyllin-Eosine). Hasil penelitian menunjukkan adanya perubahan struktur sel hepatosit hepar pada perlakuan yaitu degenerasi midzonal dan nekrosis. Hal ini menunjukkan adanya pengaruh pemberian perlakuan air rebusan mi instan terhadap susunan sel hepar. Penelitian menggunakan jumlah sampel organ yang terbatas sehingga perlu dilakukan penelitian dengan sampel yang lebih banyak dan diperlukan adanya analisis statistik untuk mengetahui tingkat derajat kerusakan sel.
\end{abstract}

Kata kunci: Histologi; Hepar; Mencit Bunting; Mi Instan

\section{ABSTRACT}

This study was conducted based on previous research, to test of giving instant noodle boiled water to pregnant female mice and the results showed that there were fetal abnormalities but the statistical analysis of these abnormalities was not significant. This study was conducted to determine the histology of the liver of pregnant female mice after giving instant noodle boiled water. The stages of this research are as follows: preparation of pregnant female mice that have been treated with instant noodle boiled water from 3 
different brands, namely $P 1, P 2$, and P3. Each treatment consisted of giving boiled water with different concentrations of $30 \%, 50 \%$, and 70\% for 14 days, then the mice were sacrificed and then the liver was taken, histology preparations were made, then the histological structure was observed. The method of making histology preparations followed the HE (Haematoxyllin-Eosine) staining procedure. The results showed that there were changes in the structure of the liver hepatocyte cells in the treatment, namely midzonal degeneration and necrosis. This shows that there is an effect of giving instant noodle boiled water treatment on the composition of liver cells. The study used a limited number of organ samples, so it is necessary to do research with more samples and statistical analysis is needed to determine the degree of cell damage

Keywords: Histology; Hepar; Mice Water Instant Noodle

\section{PENDAHULUAN}

Perkembangan teknologi yang pesat saat ini menuntut manusia untuk memenuhi kebutuhan dengan serba instan, salah satunya adalah makanan instan [1]. Salah satu produk makanan yang sangat digemari oleh masyarakat dari semua kalangan adalah mie instan karena rasa nya yang lezat, penyajiannya yang sangat praktis dan cepat, mudah di dapat, serta harga yang sangat terjangkau semua kalangan masyarakat [2].

Indonesia merupakan salah satu produsen dan konsumen mie instan terbesar di dunia. Indonesia juga berada di urutan kedua di dunia dalam konsumsi mie instan [3]. Berdasarkan data Riskesdas Depkes RI (2013) diperoleh informasi bahwa konsumsi mie instan di Indonesia mencapai 75 bungkus/kapita/tahun dimana 6 dari 10 orang di Indonesia mengkonsumsi mie instan lebih dari 1 kali dalam sehari [4]. Hal ini sangat mempengaruhi status gizi masyarakat Indonesia [5].

Mie instan merupakan produk yang sangat kaya akan karbohidrat, namun produk ini belum mengandung diet dan kandungan gizi yang lengkap karena kadar protein, vitamin dan mineral nya sangat rendah. Bentuknya yang kering merupakan hasil penggorengan yang kaya akan trans fat yang dapat menyebabkan penyakit jantung koroner [6]. Selain itu, produk makanan ini banyak mengandung MSG (Mono Sodium Glutamat) [7]. Penelitian menunjukkan bahwa pemberian MSG pada mencit bunting dapat menyebabkan kelainan pada perkembangan janin berupa kelainan micropthalmia, anopthalmia, acorea, dan hidrosephalus.

Mie instan ini cenderung rendah serat, tapi tinggi kalori, lemak, garam natrium, dan kolesterol. Dalam sebungkus mie instan terdapat bahan tambahan makanan yaitu: MSG, Sodium tripolyphosphat, natrium benzoat, dan tartrazine yellow [8]. Penelitian sebelumnya menunjukkan bahwa pemberian mie instan kepada tikus pada jangka panjang memiliki efek peningkatan berat badan secara signifikan tetapi menyebabkan penurunan kerja pada sistem otak [1].

Konsumen mie instan di Indonesia meliputi semua kalangan mulai dari anakanak hingga dewasa termasuk ibu hamil. Konsumsi mie instan secara terus menerus pada ibu hamil dapat menimbulkan kekurangan zat gizi yang menimbulkan berbagai masalah defisiensi yaitudefisiensi yodium, anemia zat besi, dan kekurangan vitamin seperti vitamin A, Asam folat, dan vitamin B12 [9]. Defisiensi tersebut akan memacu terjadinya kelainan pada janin yang dikandung oleh ibu hamil karena masa kehamilan membutuhkan vitamin, nutrisi, dan mineral untuk membantu proses perkembangan janin karena asupan makanan 
yang tidak sesuai pada ibu hamil akan mengganggu perkembangan sel-sel janin yang sedang aktif berproliferasi sehingga perlu dilakukan uji teratogenik kandungan mie instan terhadap mencit betina hamil sebagai informasi pendahuluan yang penting bagi masyarakat secara luas, khususnya bagi ibu hamil karena masalah gizi merupakan masalah utama tinggi nya angka kematian bayi di Indonesia.

Penelitian pendahuluan telah dilakukan oleh Sianturi et al. diperoleh hasil bahwa pemberian air rebusan mie instan dengan berbagai merk selama 14 hari pada mencit betina bunting mengakibatkan adanya efek kelainan pada fetus walaupun kelainan tersebut tidak signifikan [10]. Sehingga berdasarkan hasil ini perlu dlakukan uji lanjutan yaitu pengamatan struktur anatomi melalui gambaran histologi organ pada mencit betina hamil tersebut. Hal ini sesuai dengan konsep anatomi fisiologi tubuh yaitu pemberian pelakuan yang tidak memiliki efek kemungkinan akan memberi efek pada struktur anatomi organ tubuh yang berkaitan dengan perlakuan tersebut. Pada penelitian ini diamati gambaran histologi organ pada mencit betina bunting yaitu hati, pankreas, dan ginjal sebagai organ yang sangat berpengaruh pada pemberian perlakuan.

\section{METODOLOGI}

\section{Alat dan Bahan}

Alat yang digunakan dalam penelitian adalah: kertas saring, timbangan analitik, gelas ukur, pipet ukur, aluminium foil, spatula, beaker glass, pinset, gunting bedah, kertas milimeter, kamera digital, mikroskop, lup, masker, dan sarung tangan.

Bahan yang digunakan adalah larutan formalin, Parafin, Akuades, $\mathrm{KOH} 1 \%, \mathrm{Na}$ CMC, Pewarna Giemsa, Alkohol, Toluen, cover glass, dan object glass. Bahan uji yang digunakan adalah air rebusan mie instan merk ${ }^{\circledR}$ Indomie, ${ }^{\circledR}$ Mie Sedap, dan ${ }^{\circledR S}$ Super Mie. Pemilihan produk tersebut berdasarkan data yang paling banyak dikonsumsi oleh Masyarakat Indonesia.

\section{Metode Penelitian}

Penelitian ini menggunakan hewan uji mencit betina bunting yang sudah diberi perlakuan pemberian air rebusan mie instan selama 14 hari. Perlakuan tersebut terdiri dari 4 kelompok, yaitu kontrol negatif dan kelompok perlakuan (air rebusan mie instan konsentrasi 30\%, 50\%, dan 70\%) yang kemudian perlakuan ini diberi kelompok lagi berdasarkan merk mie instan yang berbeda. Pemeriksaan histopatologi organ hepar diamati melalui hasil gambaran histologi dengan pemeriksaan masing-masing organ dan diagnosa berdasarkan hasil tersebut. Untuk pengamatan organ hati/hepar yang diamati adalah gambaran histologi dengan mengamati ada atau tidak adanya degenerasi sel dan nekrosis. Air rebusan mie instan dijadikan menjadi 3 konsentrasi yaitu 30\%, 50\%, dan 70\% dengan penambahan aquadest. Bahan uji kemudian diberikan secara oral dengan menggunakan jarum sonde pada mencit hamil selama 10 hari berturut-turut mulai hari ke-6 sampai hari ke-15 kehamilan, tanpa mempuasakan hewan. Pembedahan dilakukan pada hari ke-18. Mencit dikorbankan dengan dislokasi leher, kemudia embrio dikeluarkan dan diamati apakah terdapat tapak resorpsi, jumlah embrio, embrio yang masih hidup, dan embrio yang telah mati. Setelah itu embrio dikeringkan dengan tisu dan ditimbang berat masing-masing embrio untuk mengetahui berat rata-rata kelahiran. Kemudian sebagian embrio direndam dengan larutan Bouin's dan diamati ada tidaknya kelainan pada organ melalui teknik pembuatan histologi dengan metode HE (Haemotoxylin-Eosin) [11]. 
HASIL DAN PEMBAHASAN

4.1 Hasil Penelitian

4.1.1 Hasil Uji Histopatologi Hepar Pada Pemberian Air Rebusan Mie Instan (Indomie)

A. Pengamatan Perlakuan-1: Pemberian Air rebusan Indomie 30\%

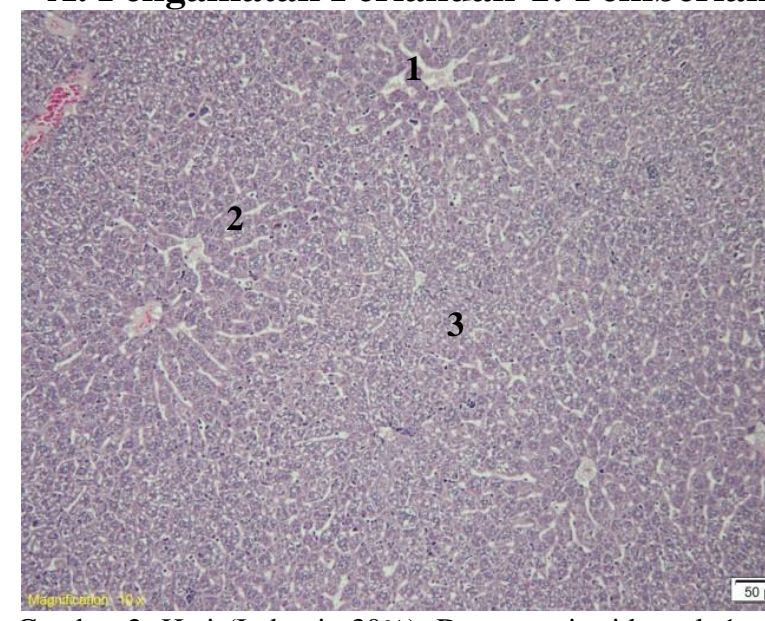

Gambar 2. Hati (Indomie 30\%). Degenerasi midzonal. 1. Vena centralis, 2. Sel epitel hati, dan 3. Degenerasi sel epitel hati. HE. x100

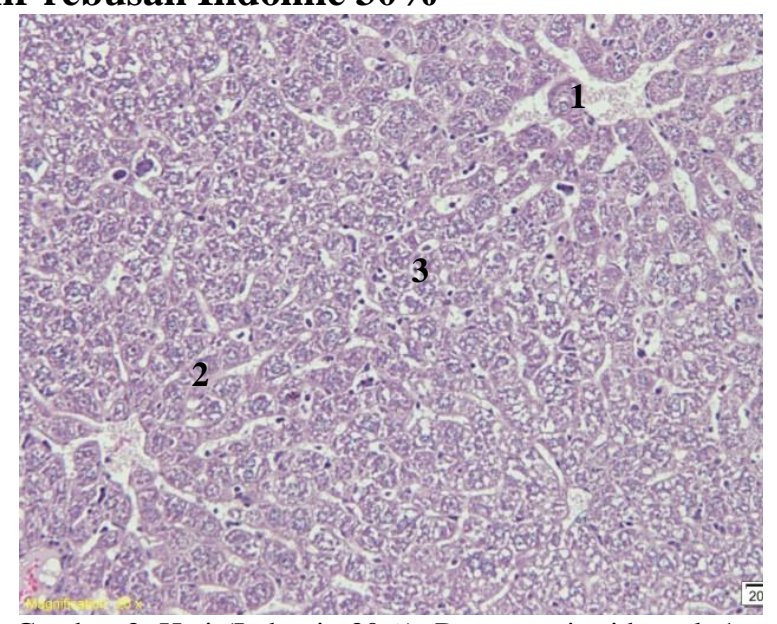

Gambar 3. Hati (Indomie 30\%). Degenerasi midzonal. 1. Vena centralis, 2. Sel epitel hati, dan 3. Degenerasi sel epitel hati. HE. x200

\section{B. Pengamatan Perlakuan-1: Pemberian Air rebusan Indomie 50\%}

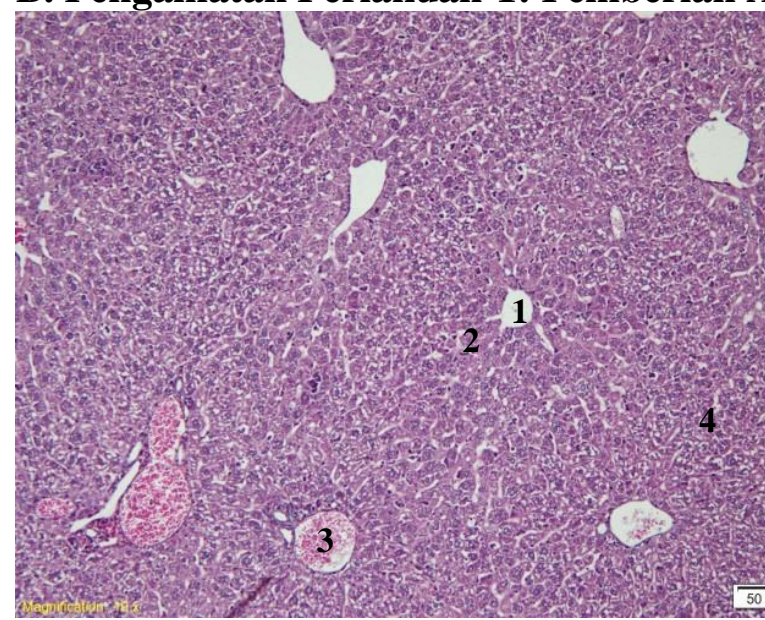

Gambar 4. Hati (Indomie 50\%). Degenerasi midzonal. 1. Vena centralis, 2. Sel epitel hati, 3. Portal tract, dan 4. Degenerasi sel epitel hati.HE. x100

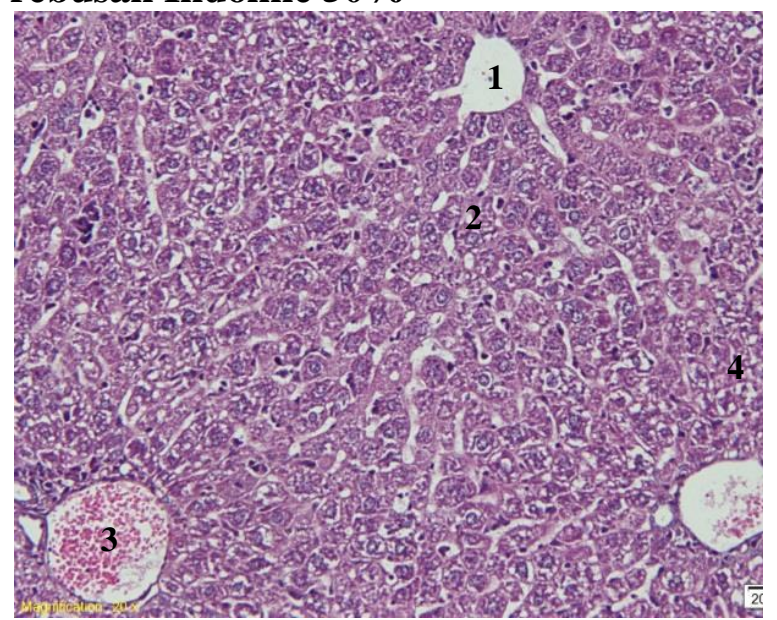

Gambar 5. Hati (Indomie 50\%). Degenerasi midzonal. 1. Vena centralis, 2. Sel epitel hati, 3. Portal tract, dan 4. Degenerasi sel epitel hati.HE. x200 


\section{Pengamatan Perlakuan-1: Pemberian Air rebusan Indomie 70\%}

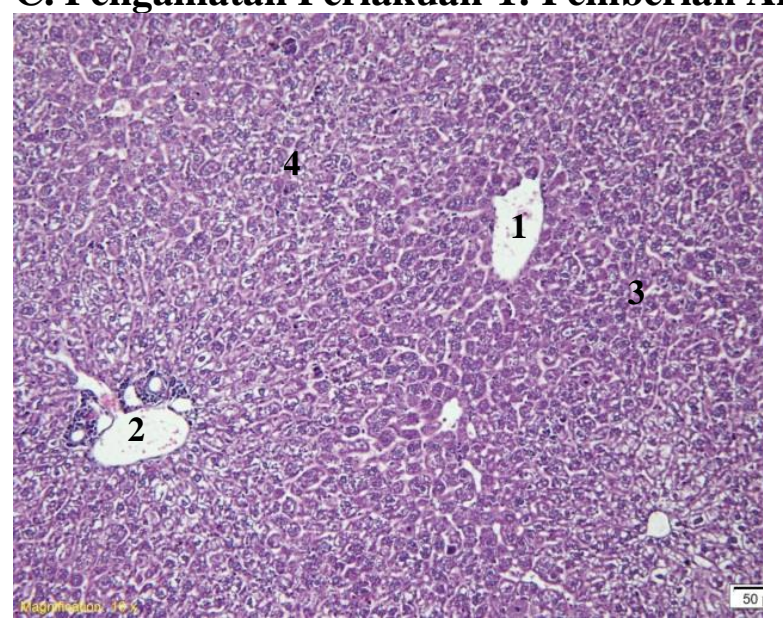

Gambar 6. Hati (Indomie 70\%). Degenerasi midzonal. 1. Vena centralis, 2. Sel epitel hati, 3. Portal tract, dan 4. Degenerasi sel epitel hati. HE. x100

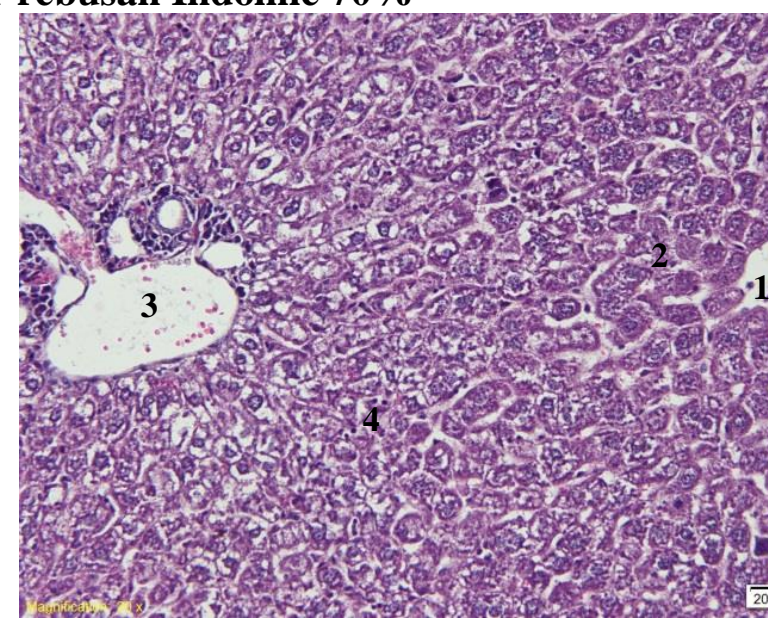

Gambar 7. Hati (Indomie 70\%). Degenerasi midzonal. 1. Vena centralis, 2. Sel epitel hati, 3. Portal tract, dan

4. Degenerasi sel epitel hati. HE. x200

Hasil penelitian pada gambar di atas menunjukkan gambaran histologi organ hepar mencit betina bunting setelah pemberian perlakuan air rebusan mi instan merk Indomie dengan konsentrasi $30 \%, 50 \%$, dan 70\%. Secara umum gambaran histologi menunjukkan adanya degenerasi midzonal dengan terbentuknya vakuola pada jaringan sel hati dan pembendungan pada hati. Bagian penting lain dalam pengamatan struktur histologi organ hepar adalah bagian vena centralis.

Pada perlakuan di atas tampak adanya kondisi vena centralis yang sedikit melebar tetapi belum mengalami nekrosis. Bagian vena centralis ini menjadi indikator penting dalam pengamatan histologi hepar. Hal ini karena daerah vena centralis merupakan pusat lobules hati dan berdasarkan aliran peredarah darah, bagian vena centralis merupakan bagian yang menerima paling sedikut oksigen sehingga apabila terjadi gangguan maka akan terlebih dahulu mengalami kerusakan dan terlihat lebih parah. Jika terjadi kerusakan maka sel penyusun dari vena centralis akan rusak atau lisis yang berdampak dengan pelebaran diameter vena centralis. Biasanya diameter ini menjadi dasar penentuan normal atau rusaknya sel penyusun organ hepar

Pada penelitian ini ditemukan perubahan struktur sel hepatosit akibat perlakuan pemberian air rebusan mi instan merk Indomi yaitu terjadinya degenerasi. Derajat degenerasi dibedakan atas tiga tingkatan yaitu degenerasi tanpa kerusakan, degenerasi sedang, dan nekrosis berat. Dengan kata lain, gambaran histologi hepar pada perlakuan pemberian air rebusan mi instan merk Indomie belum mencapai ke tingkat kerusakan parah yaitu nekrosis. 
4.1.2 Hasil Uji Histopatologi Hepar Pada Pemberian Air Rebusan Mie Instan (Mie Sedap) D. Pengamatan Perlakuan-1: Pemberian Air rebusan Mie Sedap 30\%

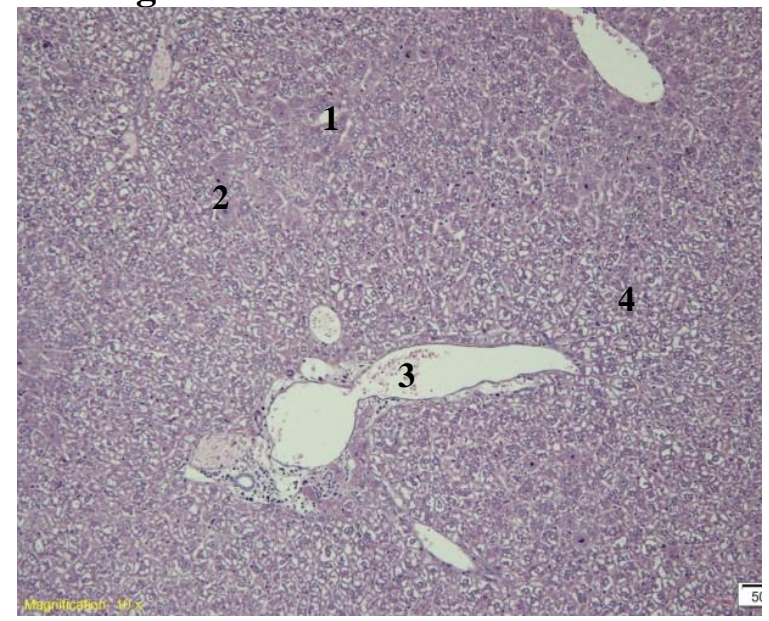

Gambar 8. Hati (Mie Sedap 30\%). Hepatik nekrosis. 1. Vena centralis, 2. Sel epitel hati, 3. Portal tract, dan 4. Nekrosis sel epitel hati. HE. x100

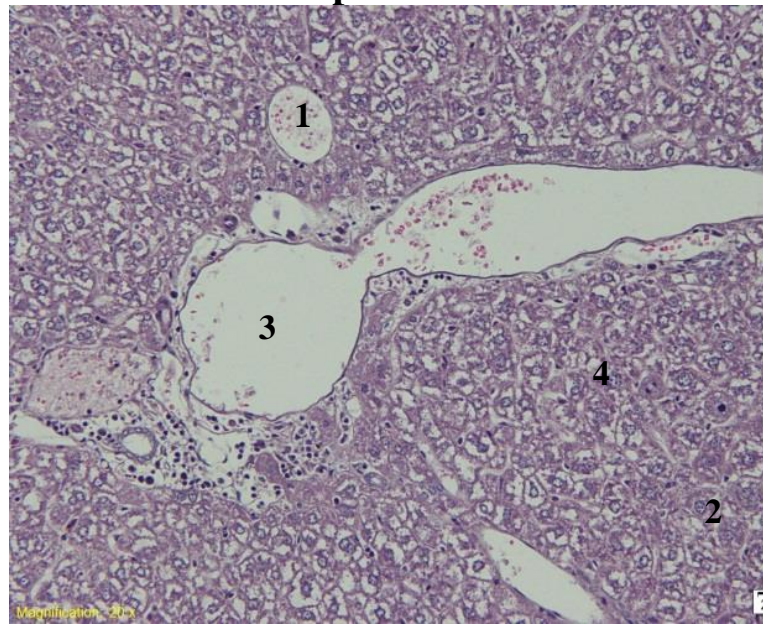

Gambar 9. Hati (Mie Sedap 30\%). Hepatik nekrosis. 1. Vena centralis, 2. Sel epitel hati, 3. Portal tract, dan 4. Nekrosis sel epitel hati. HE. x200

\section{E. Pengamatan Perlakuan-1: Pemberian Air rebusan Mie Sedap 50\%}

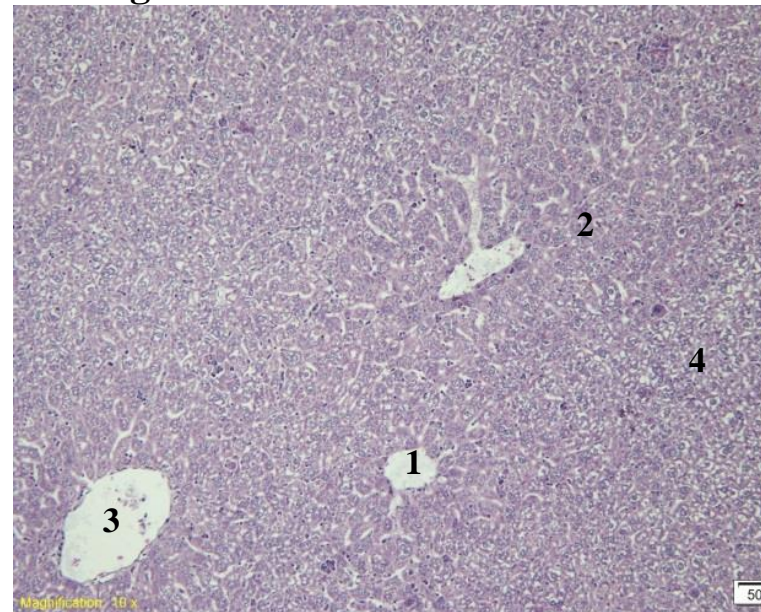

Gambar 10. Hati (Mie Sedap 50\%). Degenerasi midzonal. 1. Vena centralis, 2. Sel epitel hati, 3. Portal tract, dan 4. Degenerasi sel epitel hati. HE. x100

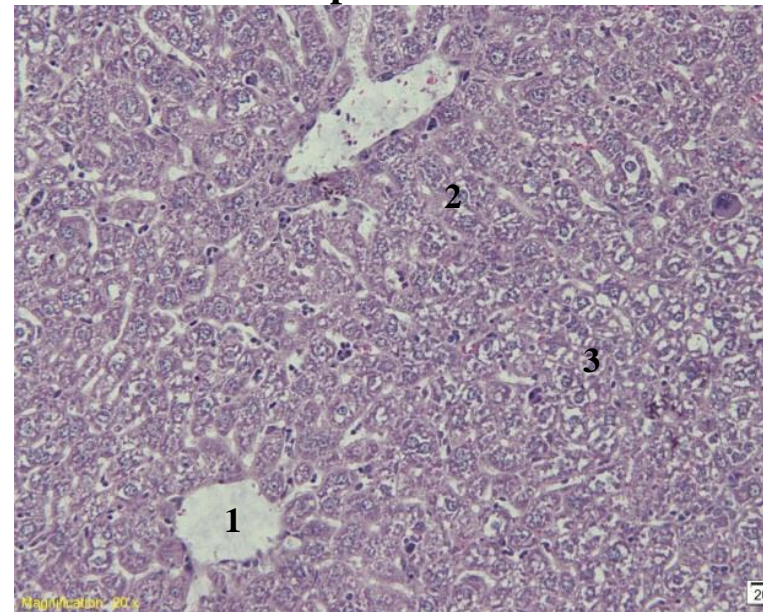

Gambar 11. Hati (Mie Sedap 50\%). Degenerasi midzonal. 1. Vena centralis, 2. Sel epitel hati, dan 3. Degenerasi sel epitel hati. HE. x200 


\section{F. Pengamatan Perlakuan-1: Pemberian Air rebusan Mie Sedap 70\%}

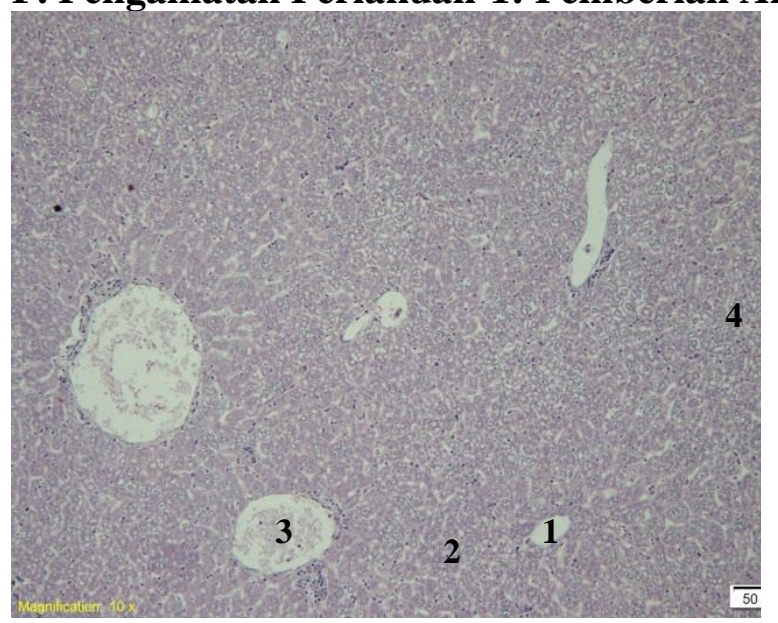

Gambar 12. Hati (Mie Sedap 70\%). Hepatik nekrosis. 1. Vena centralis, 2. Sel epitel hati, 3. Portal tract, dan 4. Nekrosis sel epitel hati. HE. x100

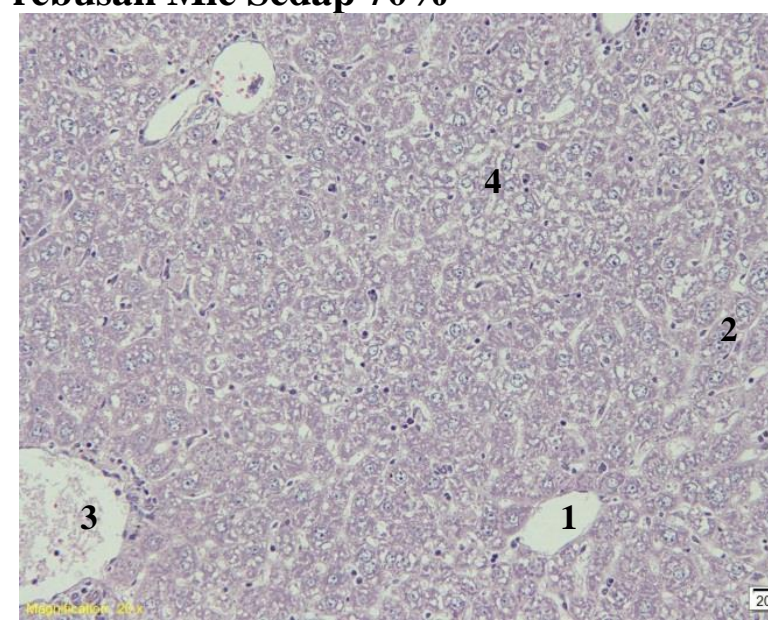

Gambar 13. Hati (Mie Sedap 70\%). Hepatik nekrosis. 1. Vena centralis, 2. Sel epitel hati, 3. Portal tract, dan 4. Nekrosis sel epitel hati. HE. x200

4.1.3 Hasil Uji Histopatologi Hepar Pada Pemberian Air Rebusan Mie Instan (Supermie) G. Pengamatan Perlakuan-1: Pemberian Air rebusan Supermie 30\%

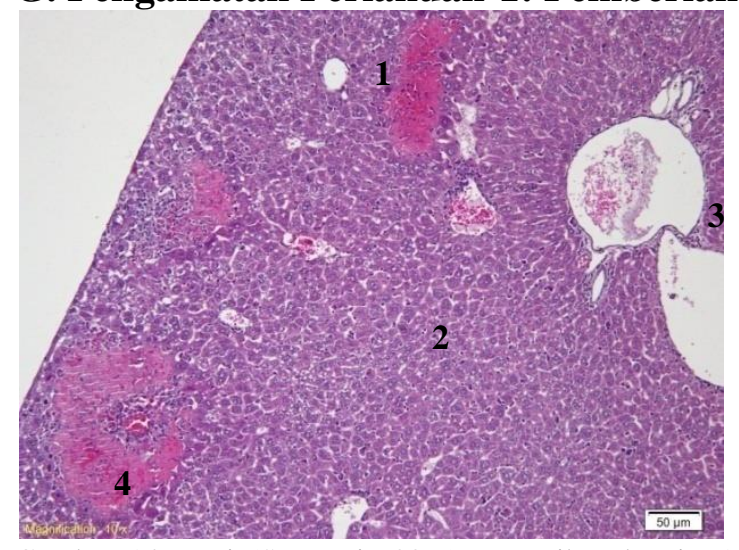

Gambar 14. Hati (Supermie 30\%). Hepatik nekrosis. 1.

Vena centralis, 2. Sel epitel hati, 3. Portal tract, dan 4. Nekrosis sel epitel hati. HE. x100

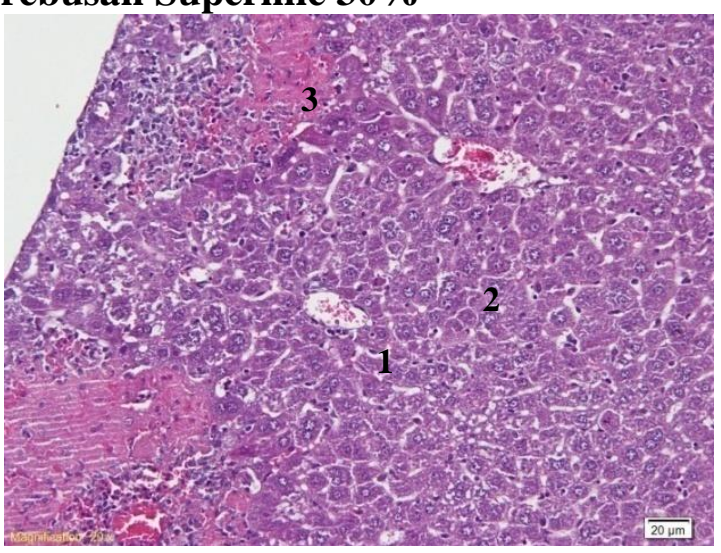

Gambar 15. Hati (Supermie 30\%). Hepatik nekrosis. 1. Vena centralis, 2. Sel epitel hati, dan 3. Nekrosis sel epitel hati. HE. x200 


\section{H. Pengamatan Perlakuan-1: Pemberian Air rebusan Supermie 50\%}

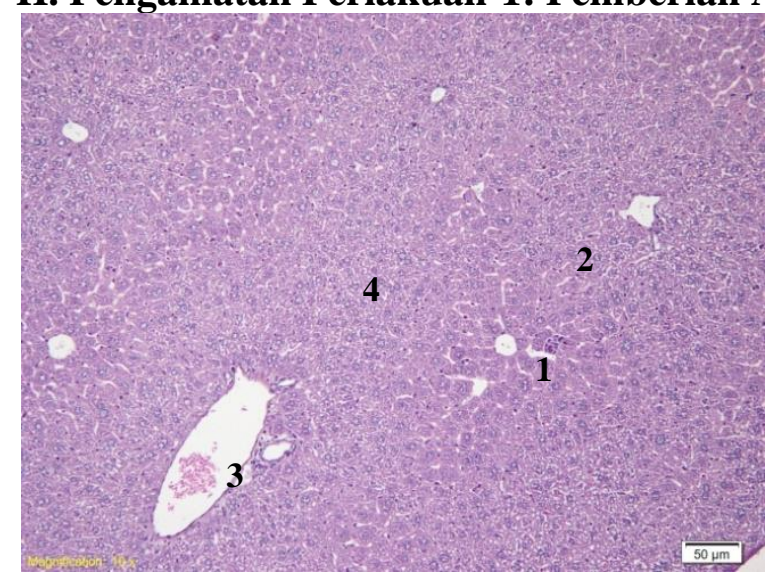

Gambar 16. Hati (Supermie 50\%). Degenerasi midzonal. 1. Vena centralis, 2. Sel epitel hati, 3. Portal tract, dan 4. Degenerasi sel epitel hati. HE. x100

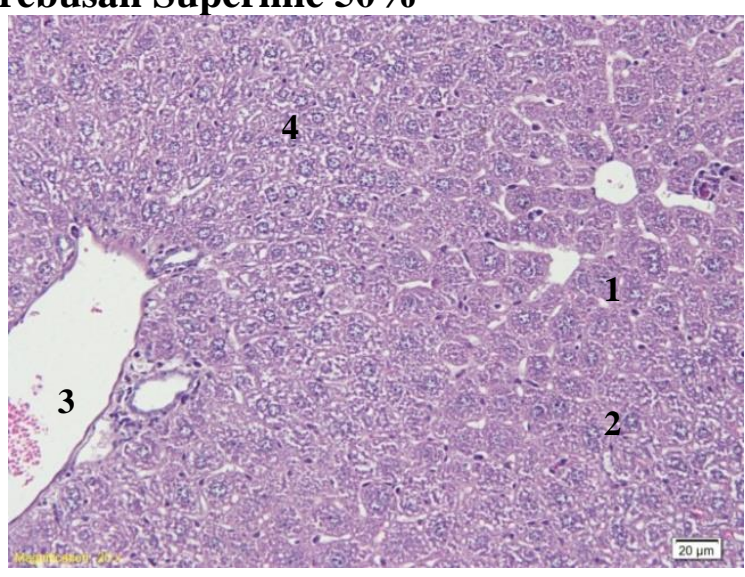

Gambar 17. Hati (Supermie 50\%). Degenerasi midzonal. 1. Vena centralis, 2. Sel epitel hati, 3. Portal tract, dan 4. Degenerasi sel epitel hati. HE. x200

\section{Pengamatan Perlakuan-1: Pemberian Air rebusan Supermie 70\%}

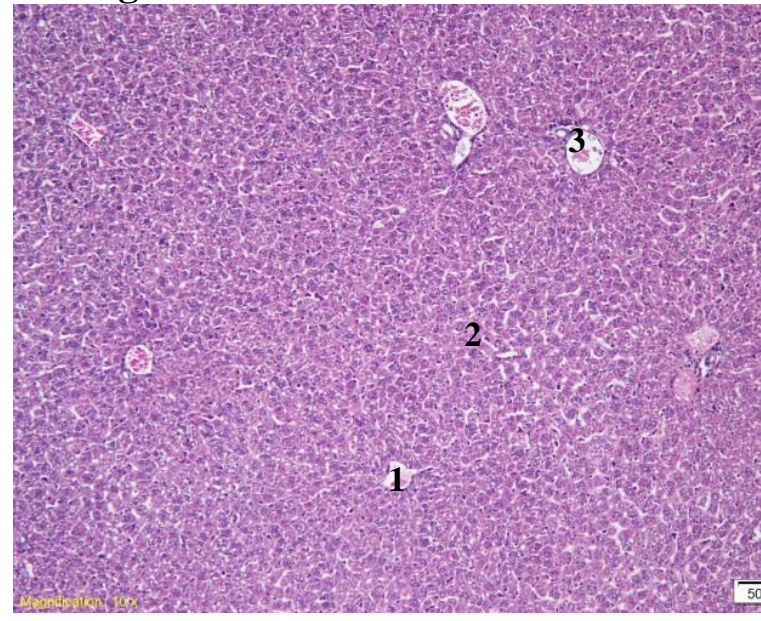

Gambar 18. Hati (Supermie 70\%). Tidak ada kelainan spesifik (taks). 1. Vena centralis, 2. Sel epitel hati, dan 3. Portal tract. HE. x100

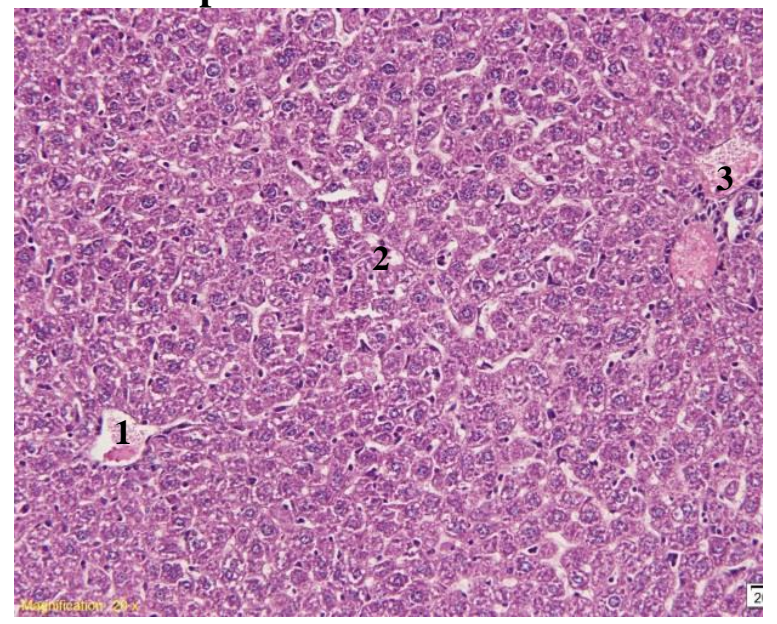

Gambar 19. Hati (Supermie 70\%). Tidak ada kelainan spesifik (taks). 1. Vena centralis, 2. Sel epitel hati, dan 3. Portal tract. HE. x200

Hasil pengamatan pada perlakuan pemberian air rebusan mi instan merk Mi Sedap dapat dilihat pada gambar 8 hingga gambar 13 dan ditemukan adanya perubahan struktur sel hepatosit yaitu degenerasi dan nekrosis. Pada perlakuan pemberian air rebusan mi instan merk Mie Sedap ini ditemukan nekrosis kemungkinan adanya kandungan pada mi instan tersebut yang menyebabkan kelainan pada struktur sel hepar. Hal tersebut terjadi juga pada perlakuan pemberian air rebusan mi instan merk Supermie pada gambar 14 hingga gambar 19 yang menunjukkan adanya kelainan struktur sel hepar yaitu ditemukannya adanya degenerasi dan nekrosis. Hal ini menunjukkan adanya perbedaan pengaruh atau dampak pemberian perlakuan terhadap struktur sel hepar. Pada perlakuan pemberian air rebusan mi instan merk Indomie ditemukan adanya degenerasi midzonal sedangkan pada perlakuan pemberian air rebusan mi instan merk Mi Sedap dan Supermie ditemukan adanya degenerasi midzonal dan nekrosis. 


\subsection{Pembahasan}

Hasil penelitian menunjukkan bahwa ditemukan perubahan struktur histologi organ hepar pada perlakuan. Perubahan struktur histologi yang ditemukan adalah terjadinya degenerasi midzonal dan hepatik nekrosis. Hal ini terjadi karena adanya paparan perlakuan yang memberikan dampak perubahan struktur organ hepar. Kandungan yang ada pada air rebusan mi instan ini memberikan dampak perubahan struktur hisologi hepar. Mi instan merupakan salah satu produk makanan yang rendah serat tetapi tinggi kalori, lemak, garam natrium dan kolesterol. Selain itu, dalam produk ini terkandung bahan tambahan makanan yaitu MSG, Sodium tripolyphosphat, natrium benzoate, dan tartrazine yellow [1].

Berdasarkan penelitian diperoleh hasil berdasarkan gambaran histologi pada semua perlakuan ditemukan perubahan struktur sel hepatosit yaitu degenerasi midzonal. Sel pada asinus hepar dibagi atas 3 zona berdasarkan sistem aliran darah dalam lobules yaitu zona 1 , zona 2 (midzonal), dan zona 3. Zona midzonal ini ditemukan di antara zona 1 dan zona 2. [12]. Sel-sel pada midzonal (zona 3) ini adalah zona yang paling dekat dengan vena sentralis sehingga mengandung sedikit oksigen dan nutrient dan yang paling sering mengalami kerusakan [13].

Salah satu penyebab perubahan struktur sel hepatosit adalah kandungan pada mi instan yang diberikan ke hewan uji. Salah satu kandungan umum pada mi instan adalah tartrazine. Tartrazine adalah pewarna sintesis yang memberikan warna kuning pada beberapa produk makanan. Bahan tambahan makanan pewarna sintesis seperti tartrazine ini lebih berbahaya apabila dibandingkan dengan pewarna alami apabila digunakan secara berlebihan. Penelitian sebelumnya yang dilakukan menunjukkan pemberian tartrazine secara oral selama 30 hari pada tikus menunjukkan adanya perubahan histopatologi hepar dan ginjal tikus disertai dengan peningkatan serum kreatini yang menngindikasikan adanya kerusakan ginjal dan hepar [14]. Selain itu, penelitian sebelumnya menujukkan bahwa pemberian tartrazine secara oral menimbulkan terjadinya perubahan struktur histopatologi hepar berupa nekrosis hepatosit. [15]. Pemberian tartrazine dapat menyebabkan kerusakan pada struktur histology hepar berupa degenerasi, kongesti vena centralis, dan nekrosis. Nekrosis merupakan tahapan akhir terjadinya kematian sel atau jaringan pada organisme hidup [16].

Selain, tartrazine diduga penyebab perubahan struktur sel hepatosit adalah kandungan Mono Sodium Glutamat (MSG) pada mi instan. MSG ini digunakan sebagai bahan tambahan penyedap rasa pada makanan. Penelitian sebelumnya yang pernah dilakukan pada tikus menunjukkan adanya perubahan struktur histologi hepar berupa dilatasi vena sentralis, lisis eritrosit, dan kerusakan hepatosit secara akut akhibat pemberian MSG dengan dosis $3 \mathrm{~g} / \mathrm{BB}$ dan 6g/BB per oral selama 14 hari berturut turut [17]. Selain itu penelitian yang lain yang pernah dilakukan menunjukkan penurunan bobot hepar dan bertambahnya diameter hepatosit mencit setelah diinduksi MSG dosis 0,084 g/bb selama 30 hari. Bertambahnya diameter ini menunjukkan bahwa pemberian MSG menyebabkan adanya pembengkakan atau degenerasi hepatosit [18]. Penelitian yang lain menunjukkan adanya perubahan struktur histology hepar tikus yang diberikan MSG dosis bertingkat yaitu $6 \mathrm{mg} / \mathrm{BB} /$ hari, $12 \mathrm{mg} / \mathrm{BB} /$ hari, dan $24 \mathrm{mg} / \mathrm{BB} /$ hari selama 21 hari.

Mengingat tingginya paparan zat toksik seperti MSG dan Tartrazine dalam konsumsi sehari hari maka perlu dikaji lebih mendalam terkait kerusakan hepar akibat paparan zat tersebut. Gambaran histologi pada hepar baik berupa degenerasi maupun 
nekrosis menyebabkan terjadinya gangguan fungsi hepar dan mendasari timbulnya berbagai penyakit hepar.

\section{KESIMPULAN}

Pemberian perlakuan air rebusan mi instan dengan merk yang berbeda yaitu Indomie, Mie Sedap, dan Supermie pada mencit selama 14 hari berturut turut dengan konsentrasi yang berbeda yaitu $30 \%, 50 \%$, dan $70 \%$ menunjukkan adanya perubahan susunan histology hepar berdasarkan gambaran histology sel hepatosit yaitu degenerasi midzonal dan nekrosis.

\section{DAFTAR PUSTAKA}

1. Villa. 2014. Perilaku Konsumsi Mie Instan Pada Balita. pp.386-401.

2. Ratnasari, D.K. \& Wirawani, Y., 2012. Gambaran Kebiasaan Konsumsi Mie Instan pada Anak Usia 7-12 Tahun. Jurnal of Nutrition College, 1, pp.537-549.

3. Adjene, J.O., Kingsley AI, Isioma C. 2017. Effects of Long Term Consumption of Indomie Noodles. World Journal of Pharmaceutical Sciences. 6(12), pp.152-158.

4. Riskesdas. 2013. Depkes RI. Jakarta

5. Sururi, M.S., 2015. Mabda Safarotus Sururi , 2014 Pengaruh Iklan Produk Mie Sedaap di Televisi Terhadap Keputusan Pembelian Universitas Pendidikan Indonesia | repository.upi.edu | perpustakaan.upi.edu. , pp.1-21.

6. Tri Arianto, N., 2011. Pola Makan Mie Instan: Studi Antropologi Gizi Pada Mahasiswa Antropologi Fisip Unair. Jurnal Antropologi Gizi, pp.1-14. Available at: http://web.unair.ac.id/admin/file/f_34835_31mie.pdf.

7. Fitri Wulandari, Viorentina Bayus, Y.W., 2015. Gambaran Tingkat Pengetahuan Mahasiswa Tentang Bahaya Mengkonsumsi Mie Instan Di Akademi Keperawatan Husada Karya Jaya Jakarta, 2014. Akademi Keperawatan Husada Karya Jaya, 1, pp.21-24.

8. Merry Wahyuningsih, 2013. Bahaya Kesehatan yang Mengintai di Balik Nikmatnya Mi Instan. Jurnal Pangan dan Agroindustri, p.1.

9. Riska, R. \& Jus, I. 2013. Hubungan Antara Konsumsi Mie Instan, Asupan (Energi, Protein, Vitamin A dan Fe) dan Status Gizi Laki-Laki Usia 19-29 Tahun di Pulau Sumatera (Analisis Data Sekunder Riskesdas 2010). Nutrire Diaita.Vol.5 No.1

10. Sianturi, Sister., AF, Muti., MB, Perdana. 2020. Uji Teratogenik Air Rebusan Mie Instan Selama Masa Kehamilan Mencit Betina (Mus musculus) Melalui Pengamatan Kelainan Morfologi Fetus. Jurnal Sains dan Kesehatan 2(3), Hal.182-192.

11. Wilson JG and Fraser FG. 1978. Handbook of Teratology. Plenum Press, New York. 78-98.

12. Suriawinata, AA and Thung, SN 2007,' Liver', dalam SEMillis (eds.), Histology forpathologist, 3rdEd, Lippincott Williams and Wilkins, Philadelphia, Pp. 688-689

13. Junquiera, LC and Carneiro, J 2012. Histologi dasar, Edisi 10. trans. A Dharma, EGC, Jakarta.

14. Amin, KA., Hameid, A., Elsttar, A.,2010. Effect of food azo dyes tartrazine and carmoisine on biochemical parameters related to renal, hepatic function and oxidative stress biomarkers in young male rats [serial online] [cited 2017 March 17]. Available from: URL: https://www.ncbi.nlm.nih.gov/pubmed/20678534 
15. Rizki, M., 2018. Pengaruh pemberian pewarna sintetis makanan tartrazine peroral terhadap lgambaran nekrosishepatosit tikus putih (Rattus norvegicus) jantan galur wistar. Skripsi. Fakultas Kedokteran Malikussaleh, Lhokseumawe

16. Guyton, A.C., Hall, J.E., 2007.Buku ajar fisiologi kedokteran, edisi 11, diterjemahkan oleh: Irawati, Ramadhani, Indriyanti, Dany, Nuryanto, Rianti, Resmisari, Suyono. EGC, Jakarta

17. Eweka, AO., Om'iniabohs, F. 2008. Histological studies of the effect of monosodium glutamate on the liver of adult wistar rats. Journal of Gastroenterology; 6(2): 1-9

18. Anindita, R. 2012. Potensi teh hijau (Camelia sinensis L) dalam perbaikan fungsi hepar pada mencit yang diinduksi monosodium glutamat (MSG). Buletin Anatomi dan Fisiologi; $X X(2): 15-23$ 